\title{
Economic development and industrial relations: the case of South and Southeast Asia
}

\author{
Sarosh Kuruvilla \\ School of Industrial and Labor Relations, Cornell University \\ C. S. Venkataratnarn \\ International Management Institute, New Delhi
}

This article outlines the close relationship between economic development and industrial relations in South and Southeast Asia. After an examination of key industrial relations features, the authors discuss emergent global trends and current Asian realities, and highlight lessons from the Asian experience, and the implications for the future.

The South and Southeast Asian region is distinctive in economic terms for several reasons. Despite accounting for roughly one half of the world's population (2.863 million), parts of this region have been the fastest growing areas in the world in the 1980s, while other parts have lagged severely behind. Between 1965 and 1990, the average rate of economic growth between 1965 and 1990 has exceeded $5 \%$ per annum in Southeast Asia, but only $1.8 \%$ in South Asia, compared to $2.2 \%$ for the OECD countries. $1.7 \%$ in Latin America, and $0.2 \%$ in sub Saharan Africa. Southeast Asia has enjoyed high export growth; in some countries exports exceeded $12 \%$ per annum, whereas world exports grew at only $5.5 \%$ during 1970-1992. The average savings rates in several Southeast and South Asian countries are high, and in some cases as high as 30\% of GDP. In recent years, the South and Southeast Asian region has accounted for fully $50 \%$ of the inflows of foreign direct investment to developing countries.

A recent World Bank report trying to explain the dramatic growth of Southeast Asia is largely inconclusive since it finds support for two competing explanations [1]. More specifically, the neoclassical explanation highlights the importance of several factors, including low inflation, a stable legal and political framework, open economic systems, and undistorted prices. The revisionist explanation highlights deliberate state intervention via protection and price distortions. However, there is consensus in the World Bank report, as well as in the writings of various experts that industrial relations and human resource policies of governments have been critical to the success of these economies [2]. 
Table 1: Economy and Social Indicators: Selected Countries 1993

\begin{tabular}{|c|c|c|c|c|c|c|}
\hline \multirow[t]{2}{*}{ Country } & \multirow{2}{*}{$\begin{array}{l}\text { Population } \\
\text { millions }\end{array}$} & \multirow{2}{*}{$\begin{array}{c}\text { GNP/Capita } \\
1992 \text { US\$ }\end{array}$} & \multicolumn{3}{|c|}{ Percent of Labour Force in } & \multirow{2}{*}{$\begin{array}{l}\text { Literacy } \\
\text { Percent }\end{array}$} \\
\hline & & & Agri. & Ind. & Services & \\
\hline Hongkong & 5.80 & 15360 & 0.2 & 23.5 & 76.3 & 90 \\
\hline Singapore & 2.80 & 15360 & 0.3 & 37.5 & 62.2 & 92 \\
\hline S. Korea & 22.60 & 6790 & 7.0 & 46.2 & 46.8 & 96.8 \\
\hline Taiwan & 20.44 & 10196 & 3.7 & 42.6 & 53.7 & - \\
\hline Malaysia & 18.80 & 2790 & 16.1 & 43.9 & 40.0 & 80 \\
\hline Thailand & 56.10 & 1840 & 13.1 & 37.4 & 49.5 & 93.8 \\
\hline Philippines & 65.20 & 770 & 22.6 & 35.0 & 42.5 & 90.4 \\
\hline Indonesia & 191.20 & 670 & 17.9 & 42.9 & 39.3 & 84.4 \\
\hline Vietnam & 69.50 & - & 38.2 & 24.6 & 37.2 & 88.6 \\
\hline Cambodia & 8.80 & 240 & 49.4 & 16.3 & 34.4 & 37.8 \\
\hline China & 1187.40 & 470 & 16.7 & 58.4 & 24.9 & 80 \\
\hline India & 880.10 & 350 & 32.5 & 27.3 & 40.2 & 49.8 \\
\hline Pakistan & 124.90 & 400 & 25.7 & 26.0 & 48.3 & 36.4 \\
\hline Sri Lanka & 17.70 & 500 & 21.8 & 28.6 & 49.6 & 89 \\
\hline
\end{tabular}

Source: World Tables, 1994.

Human Development Report 1994, UNDP

Although the preceding paragraph suggests a certain uniformity in Asian development, it is important to note that the Asian region is also very diverse economically. Whatever criteria are chosen, the region offers examples at both extremes, be it area, population, gross national product, political ideology, unemployment levels, poverty, literacy and so on. Table 1 provides some sense of the diversity in Asian economies.

Industrial relations systems in the region also exhibit diversity. The purpose of this paper is to examine the inter-relationship between economic development and industrial relations in Asia, and in particular, to highlight the trends in industrial relations over the last decade. Then, the implication of the current international context for the future of industrial relations will be examined in more detail.

\section{Economic development}

The rapid economic development of the Southeast Asian region has occurred in different time periods. In contrast to Japan (whose economic development received a spurt after post war reconstruction, although the Japanese economy had a diversified industrial base from which takeoff occurred), the Asian Tigers [NICs] (Singapore, Korea, Hong Kong, and Taiwan) commenced rapid growth during the decade of the 1960s and early 1970s. The 'emerging' tigers of Malaysia, Philippines, Thailand, and Indonesia grew the fastest in the 1980s, while it appears to be the turn of selected Asian countries notably China, Vietnam, Cambodia, Laos, and India to be the fastest growing economies in the 1990s. In 
order to set the stage for our discussion regarding industrial relations and labour policy, at least two aspects of Asian economic development merit attention.

The first significant aspect of Asian development has been the strong role played by the state in the economic sphere. Contrary to Western European and US economic development which have been led by private enterprise, South and Southeast Asian development has been managed by the state. However, there has been variation in the role played by the state in different countries. For instance, in the Japanese and Korean examples, the state influenced the nature of investment, the industries which were chosen for investment, influenced the number of firms that could enter the economic sector, and often, as in the case of Korea, actively financed private sector investment. In the case of Southeast Asia, the state's role has been more facilitative, creating the conditions necessary for the attraction of foreign investment for economic development. In the case of South Asia, particularly India and Pakistan, the state has reserved for itself the responsibility of economic development through large public sector industries. As will be argued later, the differing role of the state has implications for labour and industrial relations as well.

The second significant feature of economic development in the region has been the existence of a clearly conceptualised industrialization strategy. In East and Southeast Asia, the successful economies have followed an outward looking export oriented industrialization strategy. In contrast, in China and South Asia, the industrialisation strategy has been inward looking and focusing on import substitution. Kuruvilla suggests the existence of two primary industrialization strategies-the import substitution industrialization (ISI) strategy and the export oriented industrialisation strategy (EO1) - although within each strategy there is variability [3].

In the case of ISI, there is first stage or 'simple' IS1 based on the development of low technology consumer and industrial goods for local consumption. The focus of the industrialisation strategy is to promote the growth of locally owned industries catering to the relatively large domestic market in order to conserve foreign exchange and to promote industrialisation and local entrepreneurship. The second stage of IS1 is characterised by the development of heavy industries such as railways, atomic energy, steel, heavy chemicals, defence and space industries, where the focus of the strategy has been to create a diversified industrial base that will fuel future growth. For example, the IS1 adopted by Singapore, Malaysia, Philippines, S. Korea, and Taiwan during the early stages of their development can be classified as 'simple' while 'advanced' IS1 was characteristic of India's and China's industrialisation strategy until the 1990s. 
Similarly, the EOI strategy exhibits variation. Typically, first stage EOI in Southeast Asia has been characterised by its focus on low cost production of light manufacturing goods for exports, largely financed by foreign investment. Multinational companies in the electronics, electrical, textile, and footwear industries dominated investment in this strategy. The aims of this strategy have been to create employment and the earning of foreign exchange to repay debts to the international financing system in the case of both Malaysia and the Philippines, and in the case of Singapore, and Taiwan, this strategy was the only answer to growth given that their relatively smaller markets and lack of local capital could not sustain an IS1 strategy [4]. Second stage EOI is characterized by its concentration on technological upgradation of the first stage EOI industries, a move to higher value added products, and innovations in manufacturing process [5]. Second stage EOI in Singapore and Malaysia has been accompanied by efforts to diversify the industrial base of the economy, and is seen in the investment in large industrial projects in iron and steel, chemicals, and automobiles in several Asian countries such as Singapore, Malaysia, Korea, and Taiwan.

What is also important is that the fast growing Asian countries are currently at different levels of industrialisation. For example, Singapore, Taiwan, and S. Korea are all at the second stage export oriented industrialisation with more high value added manufacturing and higher cost and skilled labour requirements. Singapore is at a critical juncture in its industrialization where it is shifting to a service dominated economy. Malaysia and Thailand are rapidly entering this second stage, while the Philippines and Indonesia are currently low cost first stage EOI countries. Cambodia, Vietnam and Laos are emerging out of their early IS1 phases and aggressively becoming export oriented economies. India and China, both of whom for years had followed a heavy and capital intensive inward looking IS1 strategy are now gradually shifting to export oriented economies.

\section{The relationship between industrialisation and industrial relations policies Industrialisation and IR policy}

The link between industrialisation strategies and industrial relations, national industrial relations policies as well as workplace industrial relations practices, is best illustrated by the argument found in a paper by Kuruvilla [6]. In this paper Kuruvilla examines four countries, Singapore, Malaysia, Philippines and India, although the argument is true for several countries in the Asian region. The argument is delineated in Figure 1. 
ISI

1st Stage
National IR Policy Focus: Pluralism \& Stability

Political choices resulting in country specific institutional arrangements to meet IR policy goals

Predominant Pattern of Workplace Industrial Relations:

- Passive human resource practices

- Paternalistic IR practices

- Pluralistic system

- Relatively tayloristic work organisation

National IR Policy: Pluralism, Stability and Productivity

Political choices resulting in country specific institutional arrangements to meet IR policy goals

Predominant Pattern of Workplace

Industrial Relations:

- Active HR practices to increase productivity

- Collaborative industrial relations practices

- Pluralistic system
EOI

National IR Policy Focus: Cost-

Containment

Political choices resulting in specific country institutional arrangement to meet IR policy goals

Predominant Pattern of Workplace Industrial RElations:

- Cost containment oriented HR practices - Union avoidance and suppressive IR practices

National IR Policy Focus: Workplace Flexibility and Skills Enhancement Political choices resulting in country specific institutional arrangements to meet IR policy goals

Predominant Pattern of Workplace Industrial Relations:

- Aggressive HR practices promoting skills development and flexible pay

- Dynamic work organisation

- Positive non-union HR practices

- Highly flexible HR systems

Figure 1: Economic (development strategies, industrial relations policies and workplace IR/HR practices

As Figure 1 indicates, there is a close association between industrialisation strategies and industrial relations policies in Southeast Asia. It appears that certain kinds of industrialisation strategies and certain kinds of national labour policies go hand in hand.

Under import substitution industrialisation, the focus of labour policy is largely pluralistic. Given that the strategy is inward looking and is therefore protected against external competition, most Asian governments have not attempted to significantly regulate industrial relations. In fact, labour policies of most of the South Asian countries (eg. India) and many of the Southeast Asian countries during their brief IS1 periods emphasised pluralism in industrial relations. In a discussion on India, it is noted that the "IS1 strategy and existing industrial relations policies are mutually sustaining. The protection afforded to Indian manufacturers from foreign competition, and a guaranteed internal market, has in the views of several observers created huge inefficiencies in several fields, including labour costs [7]. In other words, a protectionist IS1 strategy was congruent with a highly protectionist IR system that impinged negatively on the development of collaborative and flexible industrial relations".

Under first stage export oriented industrialisation, the primary focus of industrial relations policy at the national level was on cost containment. Except in the case of Korea and Japan where investment was from within, in all the other countries of Asia, export orientation has been based on the 
competitive advantage of low cost labour financed by foreign investment. It was the need to attract and retain foreign investment that drove economies to enact IR policies geared towards cost containment. For example, both Malaysia and the Philippines enacted rules that restricted the amount of overtime, refused to legislate equal pay for equal work in export oriented industries where most of the labour was female, and exempted foreign investors from much labour and employment legislation.

The first stage EOI strategy was also predicated on providing investors with cheap, flexible and highly compliant labour. Here again, the approach of most countries has been to suppress the growth of trade unionism. Deyo has made a strong case that Asian industrialism has been based on some amount of labour subordination [8]. Several countries have banned unionisation (for example, unionisation in the export oriented electronics industry in Malaysia was banned until 1988), or otherwise restricted the ability of workers to form unions. In other cases, authoritarian regimes have suppressed union activity. S. Korea, Taiwan, Malaysia, Philippines and Indonesia have all at some time or another severely restricted the ability of workers to form unions. There is evidence that the goals of export oriented industrialization and a restrictive and exclusive labour policy are highly congruent [9].

However, in more advanced export orientation based on higher technology the focus of labour policy changes away from cost containment and union repression to the development of highly skilled and flexible, yet productive labour. Again, in all countries that have embarked on this second stage of EOI, there have been efforts to reform the education system to provide better qualified workers to the growing export industry, as well as a tremendous effort to develop skills through various incentives started by the government. In Malaysia and Singapore for example, the government has introduced the concept of Skills Development Funds [10]. Employers must pay a certain percentage of payroll costs into the fund, and can reclaim a part of their contributions only if they invest in training. Both Korea and Taiwan have a history of skills development through various vocational training centers. In addition, almost all countries have decentralized bargaining structures to enable bargaining to reflect the unique conditions of individual industries and firms [11]. The point is that there is a qualitative shift in the focus of labour and industrial relations and human resources policy at the national level consequent to a change in the industrialization strategy.

The most interesting case, and one that further supports the industrialisation and industrial relations framework is the case of India. After 40 years of ISI, the shift of the Indian economy in 1992 to an export oriented one is bringing tremendous pressure on the industrial relations system to change [12]. Although the direction of change is unclear, clearly it is moving towards increased workplace 
flexibility. Therefore, it appears rather clear that Asian industrial relations policy is closely and intimately connected with the industrialisation strategies of their countries

\section{Industrialisation and IR/HR practices}

Apart from its effect on macro level IR/HR policy, the industrialisation strategy has also been shown to affect the nature of IR/HR practice in firms. In studying the effects of industrialisation on IR/HR practices in several firms in the IS1 and EOI sectors in Malaysia and the Philippines, Kuruvilla finds the following [13]. First, there are differences in IR/HR practices between the IS1 and EOI sectors in each country. In the IS1 sector, firms appear to be following more 'passive' human resource practices. In the EOI sector, in both countries, the human resource practices appear to evidence more diversity, but suggest a general pattern of more 'aggressive' and flexible IR/HR practices, that appear to fit the pattern of 'new human resource systems' alluded to by many authors. Second, these differences between the industrialisation regimes are evidenced in both countries. Third, the IR/HR practices under a more advanced EOI strategy in Malaysia differ from the IR/HR practices in first stage EOI in the Philippines, which is best exemplified by the electronics industry, which constitutes the bulk of the EOI sector in both countries.

Note that industrialisation's effects on IR/ HR practices work indirectly through the various mechanisms used by countries to attract a certain type of foreign investment, and in creating two distinct sectors within the economy. The IS1 sector, which is protected from external competition, has less need to adopt competitive human resource practices relative to the export oriented sector that must compete internationally. In addition, given that export oriented sectors are typically dominated by foreign investment, it is only natural that the diffusion of human resource innovations from investor countries will reach the exports sector quicker. The difference in workplace level human resource and industrial relations practices across the two sectors found in Kuruvilla's paper has also been found in other studies in other Asian countries [14].

\section{The institutional variation in South/Southeast Asian IR Systems}

Despite the close connection between industrialization and macro level IR policy as well as micro level IR practice, it is important to note that there is considerable variation in the specific institutions that countries have adopted to attain national level IR policy goals. In other words, although there appears to be a commonality in terms of macro level goals brought about by the industrialization strategy, there is 
considerable divergence in the rules, legislation, and institutions that have been adopted by various countries in attaining macro policy goals.

The variation in institutional arrangements are largely a product of political choices made by the state, as well as the previous institutional IR/HR history of the parties [15]. The goal in this section is to give the reader a sense of the differences in terms of approach to labour legislation and institutions in South and Southeast Asia.

\section{Labour protection}

Typically the first plank in Asian labour policy, is on labour protection, ie., labour standards, laws and welfare policies. There is a remarkable similarity in labour protection legislation in all Asian economies. All these economies are characterised by advanced legislation mandating annual leave, casual leave, maternity leave, child care (borne by employer), and legislation regarding overtime, working hours, safety and health, restrictions on terminations, severance pay, annual bonus, and retirement benefits. Protective labour legislation is advanced, certainly more so than the US, and the commonalities are explained more by the willingness of these economies to follow established ILO conventions with respect to these issues.

However, despite similar legislation, there is wide variation in enforcement of these laws. So far, Singapore is perhaps the only country where all labour standards laws are enforced in full. Several countries have revised labour standards laws downward (eg. Philippines), arguing that they are too advanced for developing economies. There is some truth in this argument, given that the models of legislation in Scandinavia have been the basis for many of these laws. In other cases (eg. Taiwan), enactment of the labour standards legislation has been the basis for increased union activity and the cause of increased labour management conflicts [16]. In general terms however, the labour standards laws 'on the books' in Asian countries are relatively advanced [17].

\section{Labour relations}

It is in the area of labour relations where one sees vastly different institutional regulation in Asia. Here we discuss several issues such as bargaining structure, union structure, the subjects of bargaining, and the right to strike. 


\section{Bargaining and union structure}

Fundamentally, there have been two approaches in Asia. The first approach, characterised by Singapore had a highly centralised bargaining system with wage increases suggested by the tripartite national wages council that were adopted economy wide. In Korea and Taiwan, centralization has been the norm during the authoritarian periods. However, in most other Asian countries, bargaining has been decentralised to the industry and firm level.

In terms of the bargaining structure at the workplace there is variation. Most countries allow only one union per workplace. However India, and recently Korea have adopted multiple union systems. In the latter countries, the absence of a sole bargaining agent has led to a large number of industrial disputes and escalating inter-union conflict and rivalry, inhibiting the ability of nations to develop stable and cooperative industrial relations [18].

During the last decade, there has been a changing trend in the bargaining structure in Asia towards increased decentralisation. For example, Singapore has completely abandoned its centralised wage determination principle, in favour of more flexible wages that reflect the differential competitive position of each industry and firm. To further facilitate decentralisation, in the early 1980s' Singapore also mandated the formation of 'house' or enterprise unions, based on the argument that a change in union structure would enhance workplace flexibility. The trend towards increased decentralisation in union structure has also occurred in Malaysia, which also has enterprise union legislation, as does Taiwan. In other countries such as Thailand, India, Philippines, bargaining and union structures are highly decentralised for the most part, and in Korea, the situation is in flux as labour policy has not yet been determined.

\section{Union federations}

There are a few countries where there is only one trade union federation such as Singapore, China and Indonesia. These federations are normally closely linked and identified with the political party in power. However, only one country allows union involvement in national level decisions. Singapore, for example, created a tri-partite framework in which the National Trade Union Congress (NTUC), and the Employers Federation (SNEF) were provided with representation on all important national bodies, including the National Wages Council, the Economic Development Board, the Housing Board, and in boards and enterprises in every sphere of govemment [19]. This form of European style social partnership has not been found anywhere else. This tripartism has been achieved also because of the creation of an 
enterprise union structure in which all enterprise unions are affiliated to one major federation, the NTUC.

The more common model in this region is the existence of multiple trade union federations. Japan, Malaysia, Philippines, India, Thailand all follow the multiple federation model, although none of these federations have any significant influence through institutionalised means on national policy. More recently, Korea only recognised one single union federation, although other federations (illegal) continue to exist. The variation in the number of federations is large. Whilst most countries have two or three major federations (mostly one for the private sector and one for the public sector), India too has 10 major federations, Pakistan has 7 major federations, and Thailand has 8 federations. The Philippines, which has a highly fragmented labour movement reports over 155 federations [20]. There is also the model where the state actively encourages the formation of rival federations to counter the opposition to the ruling regime, such as in the case of the Malay Labour Organisation [21].

Apart from the formal tripartism that exists in Singapore, tri-partism in other countries is either nonexistent or weak. It has been suggested that most Asian countries have attempted to institutionalise tripartism through formal bodies or meetings, with varied success. Many of these efforts are in the form of codes of conduct that are voluntarily agreed to by significant employer and union federations. For example, India has the Code of Conduct on Industrial Discipline which outlines the principles to be used in dismissal and in union recognition. In Indonesia, there exists a 1982 joint statement on labour relations to maintain industrial peace. Malaysia has a code of conduct for 'Industrial Harmony and Areas for Cooperation'. The Philippines has a joint communique of the 'National Tripartite Conference on Wages, Employment, and Industrial Relations', while Thailand has the 'Code of Practice for the Promotion of Labor Relations'.

However, these codes have had restricted success, largely due to the unwillingness of trade unions or employer organisations to follow the code completely, as well as with problems connected with inter-union or inter-federation rivalry, problems concerning union recognition and problems with the concept of consultation as compared with that of negotiation, ie. the difficulty in drawing clear distinctions between tripartite consultation and bipartite negotiations. As Venkataratnam suggests, these Codes have to be seen in the "political contexts in which they are agreed upon and the quality of the environment and the nature of implementation, both of which leave much to be desired" [22]. Our general finding here is that with the exception of Singapore, the single or multiple federation model does not seem to have yielded any significant influence for trade unions in national decision making. 


\section{The subjects of bargaining}

There is variation in terms of the subjects of bargaining. At one extreme is the model in India where unions and employers are allowed to bargain over any issue. At the other extreme are countries that restrict the subjects of bargaining to a considerable extent. For example, Singapore and Malaysia do not allow bargaining regarding transfers, promotions, work assignments, redundancies, layoffs and retrenchment. In its EOI phase, Korea did not permit bargaining over wages, although this has changed consequent to 1987. Taiwan's labour law does not permit bargaining over issues connected with the introduction of new technology. Another restriction often found in several countries is the need for collective bargaining agreements to be certified by the Industrial Court (Singapore and Malaysia), and the Industrial Court is empowered to refuse certification if collective bargaining agreements contain provisions that are detrimental to the national interest. The ability of unions to bargain freely therefore appears to be restricted in some countries.

\section{The right to strike}

One distinctive feature of Asian economies is that there are several administrative restrictions on the right to strike. The primary motivation to restrict the right to strike has been the argument that industrial conflict should not hamper economic development. The most common administrative restriction, found in all Asian countries is the prohibition of the right to strike in essential industries. There is considerable variation in what constitutes 'essential' with some countries like Singapore having more industries under this classification than other countries. In addition, the right to strike in the public sector is also restricted.

In addition, the right to strike is circumscribed in other ways. For example, in India, Singapore, and Malaysia, a strike or lockout must be called off once an industrial dispute is under third party mediation, conciliation or arbitration. Some countries such as Singapore and the Philippines mandate taking a strike vote by secret ballot, while other countries such as Korea enforce a two week cooling off period before strikes can occur. Perusal of the ILO yearbook of labour statistics shows that the number of strikes have declined in every Asian country during the decade of the 1980s, with the exception of Korea and Taiwan, where the number of strikes rose sharply after democratisation in 1987 [23]. 


\section{Stylised models in South and Southeast Asia}

The above discussion suggests the existence of several different models in South and Southeast Asia. For the purposes of illustration these models are presented below. Note that most Asian countries in the region have adopted models that have features of these stylized models. Note also that within these models, there have been shifts as industrialisation strategies have shifted.

\section{The tripartite and flexible Singapore Model}

The essential features of this model include the equal partnership between trade unions, employers and government in all aspects of macro-economic and macro-social policy. Wage bargaining is thus de facto centralised given the tripartite representation on the National Wages Council. However, the level of trade union influence at the national level is not matched by equivalent influence at the workplace level. At the workplace, the accent of the model is on providing employers with considerable flexibility to react to changing economic conditions

The key outcomes of this model have been largely positive. While the social partnership at the national level has ensured that Singaporean workers have a steady improvement in living standards through its economic development policies, the model has shown that it is possible to use labour policy to make the transition from first stage EOI to second Stage EOI [24]. The changes and enhancements made to the model such as the change in union structure to enterprise unions in 1981 has enhanced flexibility further. However, workplace democracy and participation is not guaranteed by the model, unless it occurs due to the changing nature of the workforce and skills. In the mid 1980s, the National Wage Council has decentralized its wage recommendations, consistent with the needs of flexibility.

\section{State-employer dominated exclusionary and flexible model}

The main features of this model suggest a strong role for the state with employers having rather greater bargaining power than trade unions. In this model, trade unions have very little influence over national issues (trade union federations are registered as societies, not unions in Malaysia). In this model, there is relatively little centralisation. Workplace industrial relations are largely similar to the Singapore model, emphasizing flexibility. In the export oriented sectors, there is very low incidence of unionism. In terms of outcomes, this model has performed very well in those countries that have successfully adopted EOI, in terms of ensuring that there have been increases in real wages and 
employment. However, these increases have often come at the expense of union representation, given that the current system permits employer tactics and strategies to effectively oppose union formation. Stability in industrial relations has been achieved by some degree of coercion, while flexibility has been promoted through institutional features.

\section{The pluralistic, decentralised and fragmented IR model}

This model is characteristic of the Philippines, which has a pluralistic IR system, in which it is easy for trade unions to form, but where they have little influence at the national level. Another feature is the extensive fragmentation of trade unions, with more than 155 federations. The lack of unity of the labour movement and the intense inter-union rivalry has resulted in very weak trade unions.

The model has had little success in increasing real wages, or workplace democracy. As Pagnucco suggests, employers are free to pursue anti-union strategies with remarkable success [25]. Government legislation, which has changed between the dictatorship and democracy periods is focused at limiting the ability of unions to strike freely in the interests of economic development.

\section{The politicised multi-union model}

This is most characteristic of India and other Southeast Asian countries. In this model, trade unions are highly politicised and their affiliation with political parties not only gives them some input on national issues through the party structure, but has also been responsible for getting very favourable protective legislation for organised workers [26]. In this model, union formation, recognition, and functioning is well protected by law, and bargaining is highly decentralised.

The model, while providing organised workers with considerable protection, has worked negatively against the development of efficiency and workplace flexibility. For example the principle of allowing multiple unions in each workplace has resulted in intense inter-union rivalry that impinges on the development of long term collaborative relationships between workers and management [27]. In addition, the inability of the employer to layoff, retrench workers or close industries without government permission (which has been useful to protect employment) has created inefficiencies [28]. Most significantly the politicisation of unions and the concept of outside political leaders functioning as enterprise union leaders results in bringing political considerations into the workplace [29]. Therefore, this model leans towards equity and protection at the expense of efficiency and flexibility. Note, 
however, that with economic liberalization in India since 1992, there is considerable pressure for reform in workplace industrial relations

\section{The newly democratic transitory model}

This model is characteristic of industrial relations in Korea and Taiwan. In both countries, the shift from authoritarian forms of government to democratic forms of government has completely destabilized established patterns of industrial relations. In both countries there has been an increase in strikes and union militancy after democratisation. Previously completely controlled by the state, industrial relations is now allowed to float freely. Employers, who have never had to deal with unions are now faced with the prospect of very little experience in negotiations. In this situation, new industrial relations policies are required. In both countries, the democratic state has been slow to articulate a new set of IR policies, and a period of experimentation and learning continues. Although this is a transitory phase in Asian industrial relations, it has relevance for other emerging economies in Asia, particularly Burma, Laos, Cambodia, Vietnam, all of which are also emerging from more authoritarian systems to more democratic ones.

The five stylised models capture most of the variation in approaches to industrial relations in Southeast Asia. Note that most countries adopt variations on one or two of these models. Most importantly, these models are also undergoing change with rapid economic development. The next section outlines the emerging trends in South and Southeast Asian economies over the last decade.

\section{Important industrial relations outcomes and trends}

Having provided a description of the variation in approaches to industrial relations, the goal in this section is to discuss significant trends in South and Southeast Asian industrial relations over the last decade

\section{Weak and declining unions}

There has not been a tradition of strong unions in Asia. In the most obvious indication of trade union strength, the density of unionisation, Asian trade unions fall way behind their Western counterparts. In 1993, the country with the highest unionization rate was S. Korea, with a union density approaching $\mathbf{3 0} \%$ of the nonagricultural workforce. Apart from Taiwan and South Korea, which have reported increases in 
trade union density post their 1987 democratisation, almost all other countries in Asia have experienced a decline in trade union density. Japan's union density has declined from a high of $30 \%$ in 1985 to $22.7 \%$ in 1992, Singapore's union density has declined from $25.5 \%$ of the labour force in 1976 to $14.4 \%$ in 1992[30]. Every other industrialised Asian nation has seen declines in union density over the last few decades.

The density of unionisation however is not always related to the power that trade unions have in the region. For example, India's trade union density (expressed as a percentage of the nonagricultural workforce) is only $2.6 \%$. However, the political orientation of trade unions and their close ties with India's political parties has ensured that the labour movement has a political influence far greater than their number suggest. Labour is the swing vote in at least $30 \%$ of all parliamentary constituencies [31]. The Indian case suggests, therefore, that trade union influence and power are not determined by sheer numbers, but to the institutional network in which unions operate, and the specific exclusionary or inclusionary policies of the state.

The shifts in industrialization strategy from IS1 to EOI has negatively impacted the ability of unions to form, and to bargain collectively. In the Southeast Asian nations in particular, the restrictions on union formation in certain sectors and export processing zones, the restrictions on the subjects of bargaining, combined with a rapidly growing economy and in real wages have dampened the ability of unions to grow and the enthusiasm of people to join unions. Apart from Singapore where unions have considerable influence at the strategic level of the economy, union influence has declined with the declines in union density. In countries such as the Philippines, the intense fragmentation of the labour movement (155 Federations and 5600 independent unions) noted by Ofreneo have weakened unions [32]. Even in India where the ties between unions and political parties have been historically strong, the introduction of economic liberalisation has polarized relations given that the political party in power was pro liberalisation, while its trade union arm has been anti liberalisation.

The fastest growing sector in most Asian economies is the export oriented sector, consisting of firms in the textile, electronics, and garments industries. This is the largest growing economic sector in Southeast Asia. This is also a sector that is almost completely union free. A recent ILO report criticizing governments for banning unions in export sectors has resulted in protests by governments.

When criticized for being authoritarian regarding unions, governments point out that real wages, even those for low skilled workers, have risen quite steadily in the post colonial period, and that this has been achieved with declining income inequality [33]. 
With the increasing adoption of the export oriented model of development, one significant trend in Asian industrial relations is the rise of the non-union model during the last decade.

\section{Decentralisation in bargaining and workplace flexibility}

As noted earlier, a second significant trend is towards decentralisation in bargaining. This movement appears consistent with developments in the advanced European and North American nations noted by Katz [34]. The decentralisation in bargaining in several Asian countries appears to be part of a larger movement towards the need for increased workplace flexibility. In every Asian country there is a clear trend towards highly flexible wages, breakdown of industry wide bargaining structures, and the spread of enterprise unions. The increasing need for workplace flexibility can be traced to several factors, notably the shift into more high tech EOI, the adoption of increasingly complex micro-electronic technologies, particularly in the export sectors, and increased competition and globalisation on an international scale, all of which have put pressure on firms to adapt flexibly to changing market conditions. A good illustration of this trend is the sudden and growing movement amongst Indian employers for workplace flexibility once India shifted from its IS1 strategy to a more liberalised economy. The trend towards decentralisation and workplace flexibility appears to be highly correlated with the level of development as well as the level of integration internationally.

\section{Worker participation}

Although worker participation in decision-making had been institutionalised in several countries in the form of Joint Labour Management Committees (most countries have one such institution), these institutions have not been noteworthy for their success, as noted earlier. In the fast growing Southeast Asian nations, there is now a resurgence in worker participation, fueled by different reasons. This trend is noticeable particularly in the higher technology oriented export oriented electronics sectors. For example, Rajah suggests that higher end processes such as chip design, wirebonding and research and development operations are increasingly being located in Malaysia [35]. Work organisation in the electronics industry mirror practices followed in the advanced countries, while human resource 
management techniques are based increasingly on the development of skills with high pay and employee involvement in an increasingly non-union environment [36].

\section{Increased emphasis on training, productivity and new payment forms}

The shift into higher technology intensive industries for export, the diffusion of new technologies that call for more skilled and participative workers has also brought with it changes in the methods of wage payment. For example in Malaysia, under the low cost EOI phase, compensation policies in the electronics industry were geared towards keeping costs low [37]. Wages were kept to minimum levels, and the government's persistent refusal to enact equal pay for equal work legislation, allowed the industry to employ young women at wages less than $60 \%$ of average male wages [38]. Workers were paid by a variety of piece rates and production incentives above the daily base rate [39].

In the higher tech EOI phase, pay systems are increasingly looking like pay systems in more advanced economies. New forms of work organisation have brought with them new methods of training and wage payment systems. Increasingly, wages are tied to learning new skills, and Rajah notes that in many semiconductor companies, a production worker needs to know at least three processes to become a super operator with salaries reaching almost $750 \mathrm{M} \$$ a month (US\$301) [40]. The average wage in the electronics industry is about $350 \mathrm{M} \$$ (US\$167) per month).

In addition to pay systems, there has been increased attention to training to upskill the workforce to sustain the higher tech EOI strategy. Both governments and firms have demonstrated an increase in training efforts. For example, in Penang (Malaysia), the electronics companies in Penang who are fierce competitors in the global market have begun collaborative efforts for skills development. They have formed the skills development centre, where each company contributes equipment and training professionals to train skilled workers for the entire industry [41]. These firm level efforts are, of course, buttressed by national level efforts to increase workforce skills, via the introduction of Skills Development Funds in Malaysia and Singapore, or by extensive restructuring of the education sector.

\section{Increased focus on job security}

One consequence of the rapid development of the Asian region has been the shortage of labour in several countries (although this is less true of South Asia, China, Philippines and Indonesia). The labour shortage has, in turn, brought about increased job security in the Southeast Asian economies. For 
example, in Singapore and Malaysia, the use of temporary or casual workers has declined considerably in the 1980s, while the use of subcontracting internationally has increased. In addition, Singapore, Malaysia, S. Korea, Taiwan, all have introduced guest worker programmes, using the surplus skilled and unskilled labour from Philippines, India, and Indonesia and Pakistan.

\section{Decline in industrial conflict}

Table 2: Union membership density and strikes: selected countries

\begin{tabular}{lccccc}
\hline & \multicolumn{2}{c}{$\begin{array}{c}\text { Union } \\
\text { membership } \\
\text { density }\end{array}$} & & \multicolumn{2}{c}{$\begin{array}{c}\text { Number of } \\
\text { strikes }\end{array}$} \\
\cline { 6 - 7 } \cline { 6 - 7 }$\quad$ Country & 1980 & 1992 & & 1980 & 1990 \\
Hongkong & 16.1 & 21.2 & & 37 & 15 \\
Singapore & 24.5 & 14.5 & & 0 & 0 \\
S. Korea & 20.1 & $30.0^{*}$ & & 407 & 322 \\
Taiwan & 20.4 & 34.9 & & $626^{* *}$ & $1860^{* *}$ \\
Malaysia & 16.0 & 10.1 & & 39 & 17 \\
Thailand & 11.3 & 7.0 & & 18 & 9 \\
Indonesia & - & 3.0 & 198 & 61 \\
India & 1.1 & 2.6 & 2797 & 1825 \\
\hline
\end{tabular}

* Estimated

** Figures include all disputes, not just strikes

Note: Union density is not calculated in the same way in all countries. Some of them use union members as a percentage of civilian workforce, while others calculate on the basis of the nonagricultural workforce.

Source: Foreign Labor Trends, US Department of Labor.

One very clear trend has been the decline in the number of strikes in South and Southeast Asia. At the low end, Singapore has reported zero strikes in the last five years. At the highest end, the number of strikes in India have also declined substantially over time. Table $\mathbf{2}$ provides some indication of the decline in conflict. In interpreting these figures, one must be careful, since a decline in strikes does not 
mean that labour-management cooperation is increasing. For example, in Malaysia and the Philippines, the decline in strikes has been accompanied by an increase in industrial disputes. In other cases, the decline in strikes is highly correlated with the decline in unions. And in Korea and Taiwan, the increase in strikes is a direct outcome of democratisation. But even in those countries, there have been declines since then.

\section{The integration of industrial relations policies with other macro policies}

The single most important trend in successful Southeast Asian economies is the increased integration across macro level policies in the interests of economic development. For example industrialisation policies are linked to industrial relations. The experience of Singapore and Malaysia have demonstrated that for successful upskilling and moving to higher technology EOI requires integration of IR policies with education policies (to provide skilled workers), human resource policies (for increased training), immigration policies and active labour market policies (to meet labour shortages) and financial and tax policies to continue to attract the right kind of foreign investment. This is perhaps the single most important lesson to be learnt from the fast developing Asian economies.

We want to emphasise, however, that these trends are more apparent in the Southeast Asian countries. South Asia however demonstrates a much more traditional picture of industrial relations, although conditions are undergoing rapid change in India. Pakistan, Bangladesh, Nepal, Sri-Lanka's industrial relations systems remain largely static.

\section{The challenge of the future}

The twenty-first century presents a vastly different economic and social environment for South and Southeast Asia, with attendant implications for industrial relations policy and practice. We briefly describe the major developments, then examine the lessons from past experience and suggest a principle that could guide the development of industrial relations for the 21st century.

There are both global and regional economic imperatives to consider. The deepening of globalisation is paradoxically co-existent with a resurgence of regionalism. At the global level is the increased integration of product markets, capital markets, and even in labour markets. The position of Asian countries in the international division of labour is rendered increasingly precarious with these changes, as capital ranges more freely. In addition, the efforts to link industrial relations issues such as 
labour rights to trade liberalisation through the World Trade Organisation following GATT, will force countries to re-examine labour policy. All these factors exert a push to be more competitive. Clearly then, industrial relations systems must also change to ensure economic competitiveness and equity, as well as providing stability and flexibility to adapt quickly to changing international market conditions.

At the same time, internal factors peculiar to each economy is bringing about pressure for industrial relations change as well. In the successful countries of Southeast Asia, the trends are towards an increased shortage of labour, an increasingly well educated and wealthy workforce who are demanding more voice in industrial and economic decision making, and who are showing signs of increased dissatisfaction with existing authoritarian regimes. In addition, in the emerging countries, such as Laos, Cambodia, Vietnam, democratisation and economic liberalisation exert pressure to enact new industrial relations policies for economic growth. The current experience of Indonesia is particularly instructive in this regard, given its rapid economic development and its poor record on labour rights. In the South Asian countries, where organised workers have enjoyed a very protective set of labour regulations, the increased pressure to open up their markets and drop protectionist barriers has resulted in pressures for more efficient industrial relations practices.

Furthermore, the movement towards the creation of regional economic blocs such as AFTA (ASEAN Free Trade Area), or APEC (Asia-Pacific Economic Zone) also imply the necessity of harmonisation of IR policies for the success of these efforts. Already informal arrangements such as the plethora of regional growth triangles that are being formed requires the setting of new and common standards of industrial relations across several countries [42]. Clearly, the next century presents several opportunities for industrial relations reform in this region of Asia.

What have we learnt from the Southeast and South Asian experience so far? We have learnt that in the successful countries of Southeast Asia, industrial relations policies and institutions are closely tied to economic development strategies, and as economic development strategies change, so do IR policies and practices. We have learnt that the focus on efficiency with the erosion of labour rights is largely a transitory phase in the case of successful economies. While economic success alone has not resulted in an increase in labour rights, democratization forces within successful economies have resulted in an increase in labour rights. We have also learnt that the long run suppression of labour movements results in destabilisation in industrial relations. We have also witnessed the rise of progressive human resource practices in a non-union environment, particularly in competitive export sectors of several economies. In addition, new micro-electronic technologies that are increasingly 
adopted bring with them new forms of worker participation in firm level decisionmaking, new wage and benefit policies and increased job security. Finally, we have learnt that industrial relations must be congruent with several other macro policies such as education, training, and immigration to facilitate economic success.

Most significantly, the increasingly widespread adoption of the Asian model of development (from first stage EOI to service oriented economies) and the differential position of several Asian countries in this ladder of Asian development has provided newly developing Asian countries with a model of development and industrial relations. For instance, the emerging economies of Laos, Cambodia, and Vietnam are adopting the development strategies of Singapore and Malaysia.

The Asian experience has shown us trends of both convergence and divergence in South/Southeastern industrial relations. The convergence appears to be in the congruence between industrial relations policies and industrialisation for economic development. The divergence is seen in the diverse industrial relations institutions and regulations adopted by different countries that are consistent with their unique political and cultural circumstances.

The wide variation in the countries in Asia prevent us from making a uniform prediction or prescription regarding the future of industrial relations. Nor is it possible to identify the features of an industrial relations system that is optimal. Industrial relations choices must be locally determined, and must be rooted in national, cultural, and institutional contexts. The Asian experience has shown us that even when there is similarity in thinking at the conceptual level, there is a significant divergence in the practical level based on the contexts in which the concepts are implemented. At this point, all we can offer are the past lessons of successful countries (described earlier) and the following key goal for industrial relations systems to adopt.

We posit that for industrial relations systems to help in both economic development and democracy, the challenge is how to achieve a stable and flexible industrial relations system that meets the twin goals of both 'efficiency' and 'equity'. The pure efficiency model can be faulted over its long term suppression of labour rights that results in conflict and destabilisation of industrial relations, such as the case in Korea and Taiwan, as well as to weak unions unable to participate in workplace decision making. Pure equity models can be faulted for their excessive labour regulations that inhibit the ability of work-places to react flexibly to a changing environment.

In adopting the principles of stability and flexibility in industrial relations such that both efficiency and equity goals are met, in the context of an increasingly global economy, several fundamental changes in the roles of industrial relations actors appear necessary. In particular, the 
decentralization of industrial relations implies that the states must devolve more power and control over industrial relations issues to employers and labour to develop solutions that reflect their unique interests and concerns. Structural and legislative changes may be necessary to ensure that labour and management have the ability to mutually solve their disagreements. Both externally and internally induced economic and social changes imply that the proposition that the state acts in the public interest or its interpretation of the public interest needs to be and will be questioned [43]. Clearly, with the increased decentralisation in industrial relations, the traditionally strong role of the state in Asia will come into question. Stephen Frenkel, in a new book on Asian Trade Unions, makes several critical arguments regarding the future scenario, that are worth note here [44].

To meet the goals of efficiency and equity in industrial relations, not only the roles of parties, but also their underlying values will come under increased scrutiny. There must be a redefinition of the commitment of the actors to principles of pluralism, freedom of association, and worker's rights. Clearly economic forces will push for increased flexibility and efficiency. However, equity and stability can be addressed only by the parties themselves. In particular, in the Southeast Asian context, the role and legitimacy of trade unions or other representative bodies for workers needs to be understood and enhanced.

In addition, if actors at the national level cannot develop institutions and solutions to meet the requirements of efficiency and equity, there will be pressure from actors at the local level or the regional level for such efforts, given the drift towards globalisation and regionalisation as well as decentralization of IR. It is clear that the locus of industrial relations policy must shift from the national to the level of the workplace in order to meet the goals of IR systems articulated above.

To meet the goals of both efficiency and equity, it is also important for countries to rethink the purpose of industrial relations rules and regulations. Kuruvilla and Erickson suggest, in the 1940s, the purpose underlying the introduction of industrial relations legislation in most countries of the world has been to minimise industrial conflict [45]. They argue that in the 1990s, there seems to have been a change in the underlying purpose from minimising conflict to how best to promote productivity, flexibility, and in some cases, increased workplace democracy. The IR system of the 21st century must come to grips with these issues.

Finally, for industrial relations to effectively further democracy in any nation, there must be a change in the definition of workers and the coverage of existing labour legislation. In most Asian countries, only industrial workers appear to have coverage, leaving agricultural workers, rural farm 
workers, contingent workers, casual and contract labour, workers and employees in shops and establishments and small business outside the reaches of industrial relations regulation.

Therefore, our suggested goal of stability and flexibility and equity and efficiency implies many changes in the established ways of conceptualising industrial relations. It is our view that individual countries must devise their own systems and institutions that are congruent with their institutional history, national culture, and other macro policies in ways that meet the goals of stability, flexibility, efficiency and equity in industrial relations. Widespread acceptance of these goals is the only concrete principle that we have for the IR actors of the $21^{\text {st }}$ century.

\section{References}

1. World Bank Research Report, The East Asian Miracle: Economic Growth and Public Policy, Oxford, New York, 1993.

2. Deyo, F., Beneath the Miracle: Labour Subordination in East Asian Development, University of California Press, Berkeley, 1989.

3. Kuruvilla, S., 'Industrialization Strategy and Industrial Relations Policy in Southeast Asia', Industrial and Labor Relations Review, 1995. In Press.

4. Huff, W. G., 'Patterns in the Economic Development of Singapore', Journal of Developing Areas, 21, 1987, pp. 305-325.

5. Rasiah, R., 'Changing Organisation of Work in Malaysia's electronics Industry', International Labor Review, Forthcoming.

6. Kuruvilla, op. cit.

7. Kuruvilla, op. cit.

8. Deyo, op. cit.

9. Kuruvilla, op. cit.

10. Chew, S. B. and Chew, R., 'Impact of Development Strategy on Industrial Relations in Singapore', in A. Verma, T. Kochan, and R. Lansbury (Eds), Employment Relations in the Growing Asian Economies, Routledge, London,

11. Kuruvilla, S. and Erickson, C., 'Critical Junctures in Industrial Relations Transformation', Paper presented at the Fourth Bargaining Group Conference, Toronto, October 1994.

12. Venkataratnam, C. S., 'Impact of New economic Policies on the Role of Trade Unions', Indian Journal of Industrial Relations, 29, 1993,

13. Kuruvilla, S., 'the Influence of Development Strategy on Workplace Human Resource Practices: Case Studies in Malaysia and the Philippines', Human Resource Management Journal. In Press. 
14. Ibid. See also, Bhatt, B. J. and Miller, E. L., 'Industrial Relations in Foreign and Local Firms in Asia'. Management International Review, 24, 1984, p. 62-75. 1995, pp. 62-88. pp. 56-77.

15. Kuruvilla, op. cit.

16. Lee, J. S., 'Economic Development and the Evolution of Industrial Relations in Taiwan 1950-1993', in A. Verma, T. Kochan, and R. Lansbury (Eds), Employment Relations in the Growing Asian Economies, Routledge, London, 1995, pp. 8S119.

17. Kuruvilla, S. and Pagnucco, A., 'NAFTA, AFTA, and Industrial Relations in Asia'. In Harry C. Katz and Maria Cook (eds), North American Industrial Relations, Institute for Collective Bargaining, Ithaca, 1994.

18. Venkataratnam, op. cit.

19. Chiang, T. B., The Administration and Enforcement of Collective Agreements in Singapore, International Labour Organisation, Bangkok,

20. Ofreneo, R., 'Changes in the Workplace', Intersect, 7, May 1993.

21. Arudsothy, P. and Littler, C., 'State Regulation and Fragmentation in Malaysia', in Stephen Frenkel (Ed), Organized Labor in the Asia-Pacific Region: A comparative Study of Trade Unions in Nine Countries, ILR Press, Ithaca, 1993.

22. Venkataratnam, op. cit. See also Schregle, J., Labour Law in South East Asia, First Andres Bonifacio Annual Lecture Series. University of Philippines, Manila. Mimeo. 1994.

23. Park, Y. B. and Lee, M. L., 'Economic Development, Globalization, and Practices in Industrial Relations and Human Resource Management in Korea', in A. Verma, T. Kochan, and R. Lansbury (Eds), Employment Relations in the Growing Asian Economies, Rout-ledge, London, 1995, pp. 27-62.

24. Katz, H., Kuruvilla, S., and Turner, L., 'Trade Unions and Collective Bargaining', in Impediments to competitive Labour Markets: An Overview of Policy and Research Issues. The World Bank, Washington D.C.

25. Pagnucco, A., The Problem Solving Industrial Relations System in Singapore and Philippines, Master's Thesis, Cornell University, 1994.

26. Kuruvilla, op. cit.

27. Reddy, Y. R. K., 'Determination of Collective Bargaining Agency: Search for a Procedure', Indian Journal of Industrial Relations, 14, 1978, pp. 73-86.

28. Kuruvilla, op. cit.

29. Ramaswamy, E. A,, 'Indian Management Dilemma: Economic Versus Political Unions', Asian Survey, 23, 1983, pp. 976-990.

30. Begin, J., 'Industrial Relations in Singapore', in S. Frenkel and J. Harrod (Eds), Industrialization and Labor Relations: Contemporary Research in Seven Countries. ILR Press, Ithaca, 1995.

31. Venkataratnam, op. cit.

32. Ofreneo, op. cit. 
33. International Labour Organisation (ILO), World Labour Report, Geneva, ILO. 1994 (Also see volumes for the years 1990 to 1993).

34. Katz, H., 'The Decentralization of Industrial Relations: A Literature Review and Comparative Analysis', Industrial and Labor Relations Review, 47, pp. 3-22.

35. Rajah, op. cit.

36. Rajah, op. cit.

37. Grace, E., Short Circuiting Labour: Unionizing Electronic Workers in Malaysia, Insan, Kuala Lumpur, 1990.

38. Grace, op. cit.

39. Rajah, op. cit.

40. Rasiah, R., 'Production in Transition Within the Semi-conductor Industry and its impact on Penang', Journal of Malaysian Studies, 6,

$1988,8.5111$.

41. Penang Skills Development Center. Training for Change: the Way to a Better Future. PSDC, Penang.

42. Sharma, B., Verma, A. and Kuruvilla, S., 'Strategic Economic Cooperation and Growth Triangles in Southeast Asia', Paper Presented at the Changing Employment Relations and Human Resource Management Conference in Asia, Taipei, Chung-Hua Institute for Economic Research, 1994.

43. Adams, R. J., 'The Role of the State in Industrial Relations', in D. Lewin, 0. Mitchell, and P. Sherer (Eds). Research Frontiers in Industrial Relations and Human Resources, Industrial Relations Research Association, Madison, 1992.

44. Frenkel, S., Organized Labor in the Asia-Pacific Region: A comparative Study of Trade Unions in Nine Countries, ILR Press, Ithaca, 1993.

45. Kuruvilla and Erickson, op. cit. Blackwell 